\title{
Genotypic Selection for Soybean Earliness
}

\author{
Flaviane O. Ribeiro ${ }^{1}$, Adriano T. Bruzi ${ }^{2}$, Mariane C. Bianchi ${ }^{2}$, Igor O. Soares ${ }^{3} \&$ Karina B. Silva ${ }^{2}$ \\ ${ }^{1}$ Federal University of Viçosa, MG, Brazil \\ ${ }^{2}$ Plant Sciences Department, Federal University of Lavras, Lavras, MG, Brazil \\ ${ }^{3}$ Research-Timac Agro, Brazil \\ Correspondence: Karina B. Silva, Plant Sciences Department, Federal University of Lavras, Campus \\ Universitário, Caixa Postal 3037, Lavras, Minas Gerais, Brazil. Tel: 55-(35)-3829-5119. E-mail: \\ karina.rbarroso@gmail.com
}

$\begin{array}{lc}\text { Received: July 31,2019 } & \text { Accepted: September 23, 2020 Online Published: October 15, } 2020 \\ \text { doi:10.5539/jas.v12n11p169 } & \text { URL: https://doi.org/10.5539/jas.v12n11p169 }\end{array}$

\begin{abstract}
Obtaining early-maturing soybean cultivars with high yield performance has long been the focus of breeding programs. Obtaining the estimates of genetic and phenotypic parameters can assist breeders at selecting the superior genotypes. Therefore, the aim was to estimate the genetic and phenotypic parameters of progenies throughout the recurrent selection for early maturity in soybeans and to select progenies with superior agronomic traits. $\mathrm{S}_{0: 1}$ progenies were evaluated in one site during the 2015/2016 harvest using a $12 \times 12$ lattice design, with one 2-meter row plot with two replicates. The $\mathrm{S}_{0: 2}$ progenies were evaluated during the 2016/2017 harvest using an $8 \times 8$ lattice design, with one 3-meter row plot with three replicates. The $\mathrm{S}_{0: 3}$ progenies were evaluated during the 2017/2018 harvest using a $5 \times 5$ lattice design, with two 3-meter rows plots with three replicates. Both $\mathrm{S}_{0: 2}$ and $\mathrm{S}_{0: 3}$ progenies were evaluated in three different sites. The days to flowering, full maturity, first pod insertion height, plant height, lodging index and grain yield traits was evaluated. The data were analyzed using a mixed model approach. The genetic and phenotypic parameters, expected gain with selection, realized heritability, correlated response and the frequency distributions of the adjusted means were estimated. The estimates of the variance components have evidenced variability among the progenies, enabling the selection of superior genotypes. All the evaluated progenies showed good agronomic performance, combining early maturity and productive performance. When early-maturing progenies were selected, there was a reduction in days to flowering, plant height, first pod insertion height, lodging and yield.
\end{abstract}

Keywords: full maturity, genetic improvement, Glycine max L. Merr., recurrent selection

\section{Introduction}

Currently, the primary focus of the soybean-breeding programs in Brazil is to release cultivars that combine high yields and early maturity. The primary advantages of using early cultivars include the optimization of the second crop, i.e., the cultivation of a rainfed crop soon after the spring-summer crop. The use of early cultivars optimizes the second harvest, because soybeans are harvested earlier, and thus, the second crop can be sown during a period of greater water availability, which helps to support better crop development. Another advantage of early cultivars is their association with reduced pathogen pressure, especially for end-of-cycle diseases, because the crop is exposed to these factors in the field for a shorter time. Several reports in the literature have noted the successful use of early-maturing soybean cultivars (Gesteira et al., 2015; Pereira et al., 2017; Gesteira et al., 2018).

However, in addition to the early cycle, other agronomic attributes should be considered to recommend new cultivars. An alternative for combining both high yield and early maturity in the segregating population is the crossbreeding of parents with good performance for these characteristics. In this context, the use of complex populations involving several parental lines, such as the base population of a recurrent selection program, is seen as an alternative for generating variability, thus enabling a successful selection.

To obtain cultivars with reduced maturity cycles, some strategies have been reported. With the adoption of mass selection, Botelho et al. (2007) reported that recurrent selection was efficient at reducing the cycle of common bean cultivars. Another alternative is genotypic selection, which consists of evaluating progenies to select the 
ones with the lowest time needed to reach full maturity. There are no reports in the literature on the use of this strategy.

Thus, in view of the above information, the aim was to estimate the genetic and phenotypic parameters of the progenies from cycle 0 of the recurrent selection program for early maturity in soybeans and to select progenies with good agronomic attributes.

\section{Materials and Methods}

The progenies evaluated in the present study are at cycle 0 of the recurrent selection program for early maturity in soybean crops. To obtain the base population, a partial diallel cross was performed using 13 parents (Table 1).

Table 1. Parents used for the crosses and their respective maturity group (MG), growth habit (GH), characteristic of interest $(\mathrm{C})$, resistance to nematodes $(\mathrm{RN})$ and the company that owns the genetic material

\begin{tabular}{llllll}
\hline Cultivar & MG & GH & C & RN & Company \\
\hline CD250 RR & 5.5 & $\mathrm{U}^{\mathrm{a}}$ & $\mathrm{E}$ & $\mathrm{MI}$ & Coodetec \\
CD215 & 5.9 & $\mathrm{D}^{\mathrm{b}}$ & $\mathrm{E}$ & - & Coodetec \\
CD237 RR & 8.1 & $\mathrm{D}$ & $\mathrm{Y}$ & MI, MJ \& HG & Coodetec \\
5D690RR & 6.9 & $\mathrm{U}$ & $\mathrm{E}$ & - & Coodetec \\
CD2630 RR & 6.3 & $\mathrm{U}$ & $\mathrm{E}$ & $\mathrm{HG}$ & Coodetec \\
M7908 RR & 7.9 & $\mathrm{D}$ & $\mathrm{Y}$ & $\mathrm{MI}$ & Monsoy \\
5G 830 & 8.3 & $\mathrm{D}$ & $\mathrm{Y}$ & - & Dow AgroScience \\
BRS FAVORITA RR & 7.9 & $\mathrm{D}$ & $\mathrm{Y}$ & MI e MJ & Embrapa \\
V-TOP RR & 5.9 & $\mathrm{U}$ & $\mathrm{E}$ & - & Syngenta Seeds Ltda \\
NK7074 RR & 7.4 & $\mathrm{D}$ & $\mathrm{Y}$ & - & Syngenta Seeds Ltda \\
NA 5909 RG & 6.9 & $\mathrm{U}$ & $\mathrm{E}$ & - & Nidera Sementes Ltda \\
BMX Força RR & 6.2 & $\mathrm{U}$ & $\mathrm{E}$ & - & GDM \\
TMG7161 RR & 5.9 & $\mathrm{U}$ & $\mathrm{E}$ & MJ & TMG \\
\hline
\end{tabular}

Note. a/Indeterminated; b/Determined; $\mathrm{E}=$ Early; $\mathrm{Y}=$ grain yield; $\mathrm{MI}=$ Meloidogyne incognita; $\mathrm{MJ}=$ Meloidogyne javanica; and $\mathrm{HG}=$ Heterodera glycines.

The crosses were performed in a greenhouse at the Department of Agriculture of the Federal University of Lavras, or UFLA, during the 2013/2014 harvest. Manual hybridization was performed according to a procedure similar to that described by Borém et al. (2009). The seeds of the $F_{1}$ generation were multiplied during the winter of 2014 in a greenhouse, which was also in the UFLA Department of Agriculture, using two plants per pot.

During the 2014/2015 summer crop, the $\mathrm{S}_{0}$ population was grown at the Agricultural Scientific and Technological Development Center of UFLA in Minas Gerais (MG), Brazil (Muquém Farm), which is located at latitude $21^{\circ} 14^{\prime} \mathrm{S}$, longitude $45^{\circ} 00^{\prime} \mathrm{W}$ and an altitude of $918 \mathrm{~m}$. The $\mathrm{S}_{0}$ population was sown using 14 -meter rows, with 15 seeds/meter as the sowing density. At physiological maturity, 140 plants were selected for the $\mathrm{S}_{0: 1}$ progenies as a function of the agronomic traits, such as early maturity and branching.

The $\mathrm{S}_{0: 1}$ progenies were evaluated in the 2015/2016 summer crop from the experimental area of the Centro de Desenvolvimento Científico e Tecnológico em Agropecuária da UFLA, Muquém Farm, Lavras, MG, latitude $21^{\circ} 14^{\prime} \mathrm{S}$, longitude $45^{\circ} 00^{\prime} \mathrm{W}$ and an altitude of $918 \mathrm{~m}$. The plot consisted of one 2-meter row with two replicates in a $12 \times 12$ lattice (131 progenies +13 parents). The $\mathrm{S}_{0: 1}$ progenies were selected according to whether they had reached full maturity. The 51 earliest-maturing progenies were selected.

During the 2016/2017 harvest, the $\mathrm{S}_{0: 2}$ progenies were evaluated at three sites, Muquém Farm; Fazenda Milanez, located in the municipality of Itutinga, MG, latitude $21^{\circ} 17^{\prime} 52^{\prime \prime} \mathrm{S}$, longitude $44^{\circ} 39^{\prime} 28^{\prime \prime} \mathrm{W}$ and an altitude of $969 \mathrm{~m}$; and at Fazenda Grupo G7 in the municipality of Nazareno, MG, located at latitude $21^{\circ} 12^{\prime} 59^{\prime \prime}$ S, longitude $44^{\circ} 36^{\prime} 41^{\prime \prime}$ $\mathrm{W}$ and an altitude of $935 \mathrm{~m}$. The plot consisted of one 3-meter row, with three replicates, and the design was an $8 \times$ 8 lattice (51 progenies +13 parents). The 12 earliest-maturing progenies were selected to obtain the $S_{0: 3}$ progenies.

For the 2017/2018 harvest, the $S_{0: 3}$ progenies were evaluated at three sites, Muquém Farm, Milanez Farm and the Agricultural Scientific and Technological Development Center of UFLA in the municipality of Ijaci, MG (Palmital Farm), located at latitude $21^{\circ} 09^{\prime} \mathrm{S}$, longitude $44^{\circ} 54^{\prime} \mathrm{W}$ and an altitude of $920 \mathrm{~m}$. The design was a $5 \times 5$ lattice (12 progenies +13 parents). The plot consisted of two 3 -meter rows, with three replicates. 
In all the evaluated environments, a no-tillage system was adopted with furrows spaced $0.50 \mathrm{~m}$ apart. An inoculation was performed at planting, in the furrow, using Bradyrhizobium japonicum as a liquid inoculant at a rate of 1,200,000 bacteria per seed. The sowing was performed manually and thinning was performed 25 days after germination to set up the desired stand for each of the experiments. The other crop management procedures were performed according to the methodology proposed by Soares et al. (2015).

The following traits were evaluated:

- Days to flowering: $50 \%$ of the plants in the plot at full bloom, stage R2;

- Full maturity: $90 \%$ of the plants of the plot at stage R8 (full maturity);

- Bottom pod height: distance from the root neck of the plant to the insertion node of the first pod, in centimeters, of five plants taken at random;

- Plant height: distance from the root neck to the tip of the main stem, in centimeters, as measured in five plants taken at random;

- Lodging score: evaluated according to Bernard et al. (1965) using the following scores: score 1 for all upright plants, score 2 for some tilted or slightly lodged plants, score 3 for all moderately tilted plants or $25 \%-50$ lodged plants, score 4 for all severely tilted plants or $50-80 \%$ lodged plants and score 5 for more than $80 \%$ lodged plants;

- Grain yield: value in bags per hectare (bgs.ha ${ }^{-1}$ ) after conversion to $13 \%$ moisture.

The data were analyzed with R Development Core Team software (2016), using a mixed model approach (Bernardo 2010). The combined analysis was performed by considering the following model:

$$
\mathrm{y}_{\mathrm{ijkl}}=\mu+\mathrm{p}_{\mathrm{i}}+\mathrm{r}_{\mathrm{j}(\mathrm{l})}+\mathrm{b}_{\mathrm{k}(\mathrm{jl})}+\mathrm{a}_{\mathrm{l}}+(\mathrm{ta})_{\mathrm{il}}+\mathrm{e}_{\mathrm{ijkl}}
$$

where,

$\mathrm{y}_{\mathrm{ijk}}$ : observation for progeny $i$, in replicate $j$, in block $k$, in environment $l ; \mu$ : general constant associated with all observations; $\mathrm{p}_{\mathrm{i}}$ : random effect of progeny $i ; \mathrm{r}_{\mathrm{j}(1)}$ : random effect of replicate $j$ within environment $l ; \mathrm{b}_{\mathrm{k}(\mathrm{j}) \text { ) }}$ : random effect of block $k$ within replicate $j$ in environment $l$; $\mathrm{a}_{1}$ : fixed effect of environment $l$; (ta) ${ }_{\mathrm{i} 1}$ : random effect of progeny $\times$ environment interaction; $\mathrm{e}_{\mathrm{ijkl}}$ : random experimental error for observation $\mathrm{y}_{\mathrm{ijk} \mathrm{k}}$.

The variance components were estimated using the restricted maximum likelihood (REML) method. To assess the experimental quality, the coefficient of variation and the selection accuracy were estimated. The selection accuracy was determined using the following estimator (Gezan Munoz, 2014):

$$
\operatorname{rghg}=\sqrt[2]{1-\frac{P E V}{\sigma_{G}^{2}}}
$$

where,

PEV: prediction error variance of BLUP and $\sigma_{\mathrm{G}}^{2}$ : genotypic variance.

The coefficient of variation estimates were obtained by,

$$
\mathrm{CV}=\frac{\sqrt{\sigma_{\mathrm{E}}^{2}}}{\overline{\mathrm{x}}}
$$

where,

$\sigma_{\mathrm{E}}^{2}$ : environmental variance and $\overline{\mathrm{x}}$ : mean.

The heritability $\left(\mathrm{h}^{2}\right)$ at the progeny level was obtained according to the estimator proposed by Piepho and Mohring (2007) as follows:

$$
\mathrm{h}^{2}=\frac{\sigma_{\mathrm{G}}^{2}}{\sigma_{\mathrm{G}}^{2}+\frac{\sigma_{\mathrm{GA}}^{2}}{\mathrm{n}}+\frac{\sigma_{\mathrm{E}}^{2}}{\mathrm{nr}}}
$$

where,

$\sigma_{\mathrm{G}}^{2}$ : genotypic variance; $\sigma_{\mathrm{GA}}^{2}$ : variance in the genotype $\times$ environment interaction; $\sigma_{\mathrm{E}}^{2}$ : environmental variance; $\mathrm{n}$ : number of environments; $r$ : harmonic mean of the number of replicates.

The expected genetic gain from selection (GS) was estimated for all the traits at five selection proportion $(1 \%, 5 \%$, $10 \%, 15 \%$ and $20 \%)$. Estimates of the expected gain from the selection as the percentage of the mean (GS\%) were obtained using the following estimator:

$$
\mathrm{GS}(\%)=\frac{\overline{\text { BLUP's }}}{\overline{\mathrm{Y}}} \times 100
$$


where,

$\overline{\text { BLUP's: }}$ mean BLUPs for selected progenies and $\bar{Y}$ : general mean of progenies in generation $i$.

The realized heritability $\left(\mathrm{h}_{\mathrm{R}}^{2}\right)$ was estimated using five selection proportions $(1 \%, 5 \%, 10 \%, 15 \%$ and $20 \%)$, considering the following estimator:

$$
\mathrm{h}_{\mathrm{R}}^{2}=\frac{\mathrm{GS} / \mathrm{mj}}{\mathrm{ds} / \mathrm{mi}}
$$

where,

$\mathrm{h}_{\mathrm{R}}^{2}$ : heritability; $G S$ : gain from selection in generation $\mathrm{j}$, by a selection made in generation $\mathrm{i}$; $d s$ : selection differential; mi: mean of progenies in $\mathrm{F}_{\mathrm{i}}$; $m j$ : mean of progenies in $\mathrm{F}_{\mathrm{j}}$.

For the estimates of the correlated response (CR\%), the following estimator was used:

$$
\mathrm{CR}_{\mathrm{y} / \mathrm{y}^{\prime}}(\%)=\frac{\overline{\mathrm{BLUP}_{\mathrm{y} / \mathrm{y}^{\prime}}}}{\overline{\mathrm{y}}} \times 100
$$

where,

$\overline{\mathrm{BLUP}_{\mathrm{y} / \mathrm{y}}}$ : means of the BLUP of the genotypes for trait $\mathrm{y}$, by the selection made for trait $\mathrm{y}^{\prime}$ and $\overline{\mathrm{y}}$ : general mean of genotypes for trait $\mathrm{y}$.

\section{Results}

The estimates of the genetic and phenotypic parameters obtained by the combined analysis involving all the environments/generations evaluated here are presented in Table 2. The selective accuracy and the coefficient of variation are estimators of the experimental precision and evidence the quality of the conducted experiments. The accuracy estimates had a high magnitude, at over $80 \%$, for all the evaluated traits, except for the first pod insertion height and lodging. The coefficient of variation ranged from 2.94 for full maturity to 38.50 for lodging (Table 2).

The existence of genetic variability can be observed by the significance of the genetic variance components associated with the progenies. For all the traits, the genetic variance estimates differed from zero. There was a different behavior of genotypes regarding environmental variations that can be observed by the significance of the genotype $\times$ environment interaction was also significant and expressive for all the evaluated traits. The results indicate that most of the variation occurred due to the effect of the genotype and not due to the effect of the interaction except for the first pod insertion height and lodging. The proportion of phenotypic variation explained by the genetic effect is evidenced by the heritability. The heritability estimates ranged from 0.58 for the lodging trait to 0.98 for the number of days to flowering (Table 2).

The frequency distributions of the BLUP means presented in figure 1 as well as the estimates of the variance components show the presence of variability among the progenies. The frequency distributions also demonstrate the quantitative nature of the traits due to the continuous distribution.

The maximum, minimum, mean and range of variations for the combined BLUP means for all the traits and environments evaluated here are presented in Table 3. The estimates of the BLUP means show the great variation among the genotypes for all the evaluated traits. The most important trait, full maturity, presented a great variation of 110 to 139 days (Table 3 ). Of the progenies evaluated here, $40.46 \%$ had a cycle of less than 120 days, thus enabling a second harvest.

For the other evaluated traits there was also variation. The grain yield ranged from 31.69 to $105.97 \mathrm{scs} \mathrm{ha}^{-1}$. It is worth noting that $90.84 \%$ of the evaluated progenies presented a performance superior to the national average of $55.55 \mathrm{scs} \mathrm{ha}^{-1}$ (CONAB, 2018). The number of days to flowering ranged from 45 to 59 days. For the plant heights, the progenies ranged between 75.17 and $128.77 \mathrm{~cm}$. The bottom pod height ranged from 13.73 to $18.54 \mathrm{~cm}$. All the progenies received a lodging score of 1 or 2, these values show the upright plant type of the materials (Table 3). These results indicate that many progenies have phenotypes that meet the demands of modern agriculture. 
Table 2. Estimates of the genetic and phenotypic parameters for the full maturity (FM), days to flowering (DTF), grain yield (Yield), plant height (HT), bottom pod height (BPH) and lodging (Lod.) traits. The data referring to progenies $\mathrm{S}_{0: 1}, \mathrm{~S}_{0: 2}$ and $\mathrm{S}_{0: 3}$ were collected during agricultural years 2015/2016, 2016/2017 and 2017/2018, respectively

\begin{tabular}{lllllll}
\hline & FM (days) & DTF (days) & Yield $\left(\right.$ bags ha $\left.{ }^{-1}\right)$ & HT $(\mathrm{cm})$ & BPH $(\mathrm{cm})$ & Lod. \\
\hline$\hat{\sigma}_{\mathrm{Gp}}^{2}$ & $43.51^{*}$ & $23.03^{*}$ & $262.72^{*}$ & $78.21^{*}$ & $2.21^{*}$ & $0.04^{*}$ \\
$\hat{\sigma}_{\mathrm{GxA}}^{2}$ & $8.23^{*}$ & $1.38^{*}$ & $49.86^{*}$ & $12.09^{*}$ & $2.46^{*}$ & $0.09^{*}$ \\
$\hat{\sigma}_{\mathrm{Ep}}^{2}$ & 13.23 & 6.62 & 260.64 & 29.37 & 6.88 & 0.28 \\
$\mathrm{~h}^{2}$ & 0.96 & 0.98 & 0.92 & 0.96 & 0.75 & 0.58 \\
$\mathrm{r}_{\mathrm{gg}} \%$ & 91.13 & 94.37 & 84.88 & 90.77 & 67.39 & 54.70 \\
$\mathrm{CV} \%$ & 2.94 & 4.98 & 22.69 & 5.78 & 15.97 & 38.50 \\
\hline
\end{tabular}

Note. $\hat{\sigma}_{\mathrm{Gp}}^{2}$ : genetic variance; $\hat{\sigma}_{\mathrm{GxA}}^{2}:$ variance in the genotype $\times$ environment interaction; $\hat{\sigma}_{\mathrm{Ep}}^{2}:$ environmental variance; $\mathrm{h}^{2}$ : heritability; rĝg \%: accuracy; $\mathrm{CV} \%$ : coefficient of variation; and * Significant at $5 \%$ probability according to the maximum likelihood ratio test.

Table 3. Combined estimate of maximum and minimum values and the range variation in the full maturity (FM), days to flowering (DTF), grain yield (Yield), plant height (HT), bottom pod height (BPH) and lodging (Lod.) traits. The data referring to progenies $S_{0: 1}, S_{0: 2}$ and $S_{0: 3}$ were collected in agricultural years 2015/2016, 2016/2017 and $2017 / 2018$

\begin{tabular}{lllllll}
\hline & FM (days) & DTF (days) & Yield $\left(\right.$ bags ha $\left.^{-1}\right)$ & HT $(\mathrm{cm})$ & BPH $(\mathrm{cm})$ & Lod. \\
\hline Maximum & 139 & 59 & 105.97 & 128.77 & 18.54 & 2.00 \\
Minimum & 110 & 45 & 31.69 & 75.17 & 13.73 & 1.00 \\
Average & 124 & 52 & 71.14 & 93.71 & 16.42 & 1.38 \\
Amplitude & 29 & 14 & 74.28 & 31.99 & 4.81 & 1.00 \\
\hline
\end{tabular}
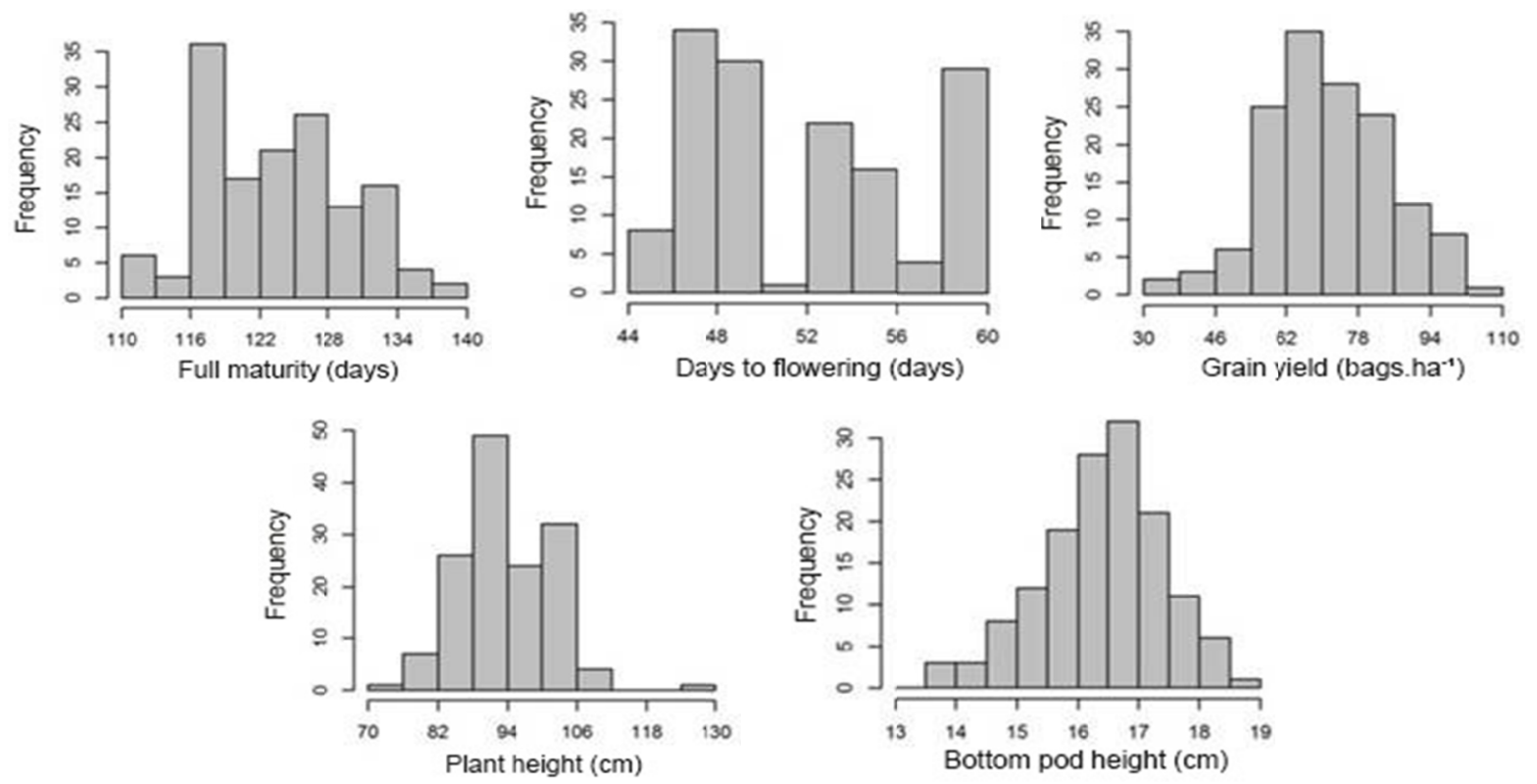

Figure 1. Frequency distribution for combined BLUP means of progenies $\mathrm{S}_{0: 1}, \mathrm{~S}_{0: 2}$ and $\mathrm{S}_{0: 3}$, from agricultural years 2015/2016, 2016/2017 and 2017/2018

The gain from selection is an important parameter to analyze in breeding programs. In this study, the gain from selection was estimated by considering different selection intensities. The estimated expected gain from the selection of progenies $\mathrm{S}_{0: 1}$ and $\mathrm{S}_{0: 2}$ are shown in Tables 4 and 5, respectively.

The estimates varied according to the selection intensities. Using higher selection intensities, i.e., selecting fewer individuals, led to a higher estimate of expected gains; however, there is decreased variability (Tables 4 and 5). It is 
worth noting that the expected gain from selection for the full maturity, days to flowering and bottom pod height traits presented negative values, because the selection acts by reducing them (Tables 4 and 5).

Table 4. Estimates of expected gain from selection (GS) for the full maturity (FM), days to flowering (DTF), grain yield (Yield), plant height (HT) and bottom pod height (BPH) traits at different selection proportion (SP). The data for the $\mathrm{S}_{0: 1}$ progenies were collected during agricultural year 2015/2016

\begin{tabular}{llllll}
\hline \multirow{2}{*}{$\mathrm{SP} \%$} & FM (days) & DTF (days) & Yield $\left(\right.$ bags ha $\left.^{-1}\right)$ & HT $(\mathrm{cm})$ & BPH $(\mathrm{cm})$ \\
\cline { 2 - 6 } & GS\% & GS\% & GS\% & GS\% & GS\% \\
\hline $1 \%$ & -8.25 & -11.70 & 45.71 & 44.42 & -31.54 \\
$5 \%$ & -6.93 & -11.37 & 36.10 & 20.84 & -26.32 \\
$10 \%$ & -6.24 & -11.23 & 31.78 & 17.34 & -23.36 \\
$15 \%$ & -5.71 & -11.10 & 28.31 & 15.26 & -21.08 \\
$20 \%$ & -5.41 & -11.00 & 25.98 & 13.87 & -19.86 \\
\hline
\end{tabular}

Table 5. Estimates of the expected gain from selection (GS) for the full maturity (FM), days to flowering (DTF), grain yield (Yield), plant height (HT), bottom pod height (BPH) and lodging (Lod.) traits at different selection proportion (SP). The data for the $\mathrm{S}_{0: 2}$ progenies were collected during agricultural year 2016/2017.

\begin{tabular}{lllllll}
\hline \multirow{2}{*}{ ISP\% } & FM (days) & DTF (days) & Yield $\left(\right.$ bags ha $\left.^{-1}\right)$ & HT $(\mathrm{cm})$ & BPH $(\mathrm{cm})$ & Lod. \\
\cline { 2 - 7 } & GS\% & GS\% & GS\% & GS\% & GS\% & GS\% \\
\hline $1 \%$ & -6.37 & -6.48 & 10.06 & 15.69 & -7.85 & -21.65 \\
$5 \%$ & -6.07 & -6.42 & 9.17 & 14.49 & -7.38 & -20.75 \\
$10 \%$ & -5.66 & -6.29 & 8.41 & 13.93 & -7.00 & -20.49 \\
$15 \%$ & -5.26 & -6.07 & 7.71 & 13.44 & -6.32 & -19.99 \\
$20 \%$ & -4.50 & -5.29 & 6.68 & 12.73 & -5.42 & -18.92 \\
\hline
\end{tabular}

The heritability estimates for progenies $\mathrm{S}_{0: 1} / \mathrm{S}_{0: 2}$ and $\mathrm{S}_{0: 2} / \mathrm{S}_{0: 3}$ are shown in Tables 6 and 7 , respectively. These estimates show the effect of the interaction, since they were always inferior to the heritability and in most cases presented negative values.

Table 6. Realized heritability estimates for the full maturity (FM), days to flowering (DTF), grain yield (Yield), plant height (HT) and bottom pod height (BPH) traits at different selection intensities. The data for the $\mathrm{S}_{0: 1} / \mathrm{S}_{0: 2}$ progenies were collected during agricultural years 2015/2016 and 2016/2017

\begin{tabular}{llllll}
\hline & $1 \%$ & $5 \%$ & $10 \%$ & $15 \%$ & $20 \%$ \\
\hline FM & -0.14 & -0.17 & -0.19 & -0.21 & -0.22 \\
DTF & -0.38 & -0.39 & -0.39 & -0.40 & -0.40 \\
Yield & -0.67 & -0.80 & -0.91 & -1.03 & -1.12 \\
HT & 0.12 & 0.26 & 0.32 & 0.37 & 0.41 \\
BPH & -0.54 & -0.64 & -0.74 & -0.82 & -0.87 \\
\hline
\end{tabular}

Table 7. Achieved heritability estimates for the full maturity (FM), days to flowering (DTF), grain yield (Yield), plant height (HT), bottom pod height (BPH) and lodging (Lod.) traits at different selection intensities. Data for the $\mathrm{S}_{0: 2} / \mathrm{S}_{0: 3}$ progenies were taken during the 2016/2017 and 2017/2018 agricultural years

\begin{tabular}{llllll}
\hline & $1 \%$ & $5 \%$ & $10 \%$ & $15 \%$ & $20 \%$ \\
\hline FM & 0.23 & 0.24 & 0.27 & 0.32 & 0.37 \\
DTF & 1.34 & 1.34 & 1.39 & 1.54 & 1.74 \\
Yield & -1.84 & -1.87 & -2.20 & -2.52 & -2.77 \\
HT & -1.21 & -1.26 & -1.31 & -1.39 & -1.43 \\
BPH & 5.26 & 5.42 & 5.89 & 6.85 & 7.57 \\
Lod. & 0.28 & 0.29 & 0.37 & 0.42 & 0.45 \\
\hline
\end{tabular}


In order to measure the effect of selection for full maturity, primary trait, correlated response estimates were observed in secondary characters (Table 8 ). This parameter allows to evaluate the progeny behavior for the different traits, considering the selection made aiming at lower absolute maturity.

With the selection for full maturity, changes in progeny performance occurred for the other traits. From the results, it is possible to observe that by selecting the earliest progenies, there is a reduction in the values of all other characteristics evaluated here.

Table 8. Estimates of correlated response for selections for full maturity, days to flowering (DTF), grain yield (Yield), plant height (HT) bottom pod height (BPH) and lodging (Lod.) under different selection proportion. Data for progenies $S_{0: 1}, S_{0: 2}$ and $S_{0: 3}$ were collected during agricultural years 2015/2016, 2016/2017 and 2017/2018

\begin{tabular}{llllll}
\hline SP\% & DTF (\%) & Yield (\%) & HT (\%) & BPH (\%) & Lod. (\%) \\
\hline $1 \%$ & -8.89 & -29.27 & -10.24 & -14.56 & 4.14 \\
$5 \%$ & -8.59 & -26.86 & -10.34 & -15.06 & -0.45 \\
$10 \%$ & -8.59 & -23.61 & -7.02 & -10.24 & -2.27 \\
$15 \%$ & -6.95 & -20.74 & -5.72 & -6.63 & -4.36 \\
$20 \%$ & -6.08 & -19.53 & -4.03 & -4.46 & -4.85 \\
$25 \%$ & -5.60 & -17.67 & -2.97 & -2.97 & -4.21 \\
$30 \%$ & -5.22 & -16.78 & -1.82 & -2.26 & -3.12 \\
\hline
\end{tabular}

\section{Discussion}

For all the evaluated traits, the estimates of the genetic variance components among progenies were significant, showing the presence of variability. This finding is essential for the selection of the best progenies and to obtain gains (Hoffmann et al., 2010). The presence of variability can also be observed by noting the range of variations between the BLUP means. According to Ramalho (2001), the parents chosen to obtain the base population in breeding programs should be as divergent as possible, in addition to presenting desirable phenotypic expressions for the highest number of traits of interest, making it possible to obtain a combination of a high mean and a high level of genetic variability. In addition to possessing genotypes with good agronomic performance, the parents used in the present study are distinct, that is, they have different genetic backgrounds and originate from different companies (Coodetec, Tropical Melhoramento Genético, Monsoy, Embrapa, Nidera, Brasmax and Dow Agroscience), which explains the good performance of the progenies and the variability observed in this study. The parents are characterized by high productive potential, early maturity and resistance to important diseases that affect soybeans, such as nematodes, which are currently a major problem in some areas.

In this study, because the progenies were evaluated in different locations and during different agricultural years, environmental factors are expected to affect the expression of the traits. The environmental effect in this case is due to the combination of predictable factors, when they are derived from systematic environmental factors or are under the control of humans, such as the planting times, spacing, soil type, permanent climate elements, altitude and latitude, among others; or they are unpredictable when they fluctuate inconsistently over the years for factors such as rainfall, Indian summers, frost, winds and the incidence of pest insects and diseases, etc. (Allard \& Bradshaw, 1964). The environmental variation associated with the variability among the progenies led to a significant genotype $\times$ environment interaction, which indicates that the progenies did not present coincident behavior under the different environments. The occurrence of genotype $\times$ environment interactions for soybeans in the state of Minas Gerais has been reported in the literature (Soares et al., 2015; Gesteira et al., 2015; Silva et al., 2015).

An important parameter to consider in breeding programs is the expected gain from selection. When considering more rigorous selection intensity, a higher gain was obtained, because individuals with higher frequencies of favorable alleles are selected. However, by selecting fewer individuals, there is a reduction in the variability in the population. It should be emphasized that the expected gain from selection of the $\mathrm{S}_{0: 1}$ progenies (Table 4) is of greater magnitude than the expected gain from the selection of the $\mathrm{S}_{0: 2}$ progenies (Table 5). This is because the $\mathrm{S}_{0: 2}$ progenies had already undergone a selection process. Therefore, the population mean was already higher and thus the expected gain from selection was lower than the expected gain from the selection of the $\mathrm{S}_{0: 1}$ progenies that had not yet undergone a selection process. In addition, another factor that may explain this difference in gain from selection from one generation to another is the fact it is not possible to isolate the component of the genotype $\times$ environment interaction in the $\mathrm{S}_{0: 1}$ generation, and thus, the genetic values are inflated. According to Rocha and 
Vello (1999), the genotype $\times$ environment interaction can reduce the correlation between the phenotype and the genotype, inflating the genetic variance, and, in turn, its dependent parameters such as its heritability and genetic gain from selection.

When multiple traits are studied, as in the present study, it is appropriate to estimate the correlated response, that is, the gain obtained in the secondary trait because of the selection for the primary trait. If two traits have a high and favorable correlation, that is, there is change in the phenotype according to the goal of the breeder it is possible to obtain satisfactory gains for the secondary trait through the selection for the primary trait. However, if the correlation is not favorable, the selection for a trait may lead to an unwanted change in the secondary trait. In the present work, the selection of the earliest progenies was performed and their behavior for the other traits was analyzed. Table 8 shows that when selecting the earliest-maturing progenies, there was also a reduction in the values of all the other evaluated characteristics (Table 8). Earlier genotypes tend to have lower plant heights and consequently lower lodging scores and lower yields.

Early cultivars tend to be less grain yield, but this is not always the case. Pereira et al. (2017) observed that increases in yield might occur when selecting progenies/lines with fewer numbers of days to full maturity. The selection of early and high yield lines can be explained by the selection of cultivars with an indeterminate or semideterminate growth habit. This is because in this type of plant, there is a greater overlap of vegetative and reproductive periods, increasing the productive potential of these cultivars (Zanon et al., 2015). In addition, the flowering of cultivars with indeterminate and semideterminate growth habits occurs in a staggered way. Therefore, if an Indian summer occurs during the flowering stage and some flowers cannot develop, the plant can produce more flowers later, and thus the yield will not be highly compromised. This finding does not occur in cultivars with a determinate growth habit, since the flowering takes place practically at the same time, throughout the whole plant.

In addition to the significance of the genotype $\times$ environment interaction, another parameter that indicates the effect of the interaction in the present study is the realized heritability. The estimates of heritability (Tables 6 and 7) indicate the strong effect of the interaction, since these were always inferior to the heritability and in most cases presented negative values. The genotype $\times$ environment interaction is often reported for different traits in the soybean crop (Vasconcelos et al., 2010; Marques et al., 2011; Barros et al., 2012; Bueno et al., 2013; Silva et al., 2015; Soares et al., 2015) and is consistent with the results of the present study. The genotype $\times$ environment interaction has been considered as one of the primary complicating factors in the work of breeders who are recommending cultivars. To minimize the effect of this interaction when selecting cultivars for traits of interest, especially those of a quantitative nature, it is necessary to evaluate the genotypes in a large number of environments. However, during the early stages of breeding programs, because many genotypes are evaluated and seeds are not often available in sufficient quantity, performing evaluations in a large number of environments is not feasible, as is the case of the present study. Tables 6 and 7 show that the realized heritability from the $S_{0: 2}$ generation to the $\mathrm{S}_{0: 3}$ generation was higher than that obtained from the $\mathrm{S}_{0: 1}$ generation to the $\mathrm{S}_{0: 2}$ generation. This is because the $S_{0: 2}$ generation was evaluated in three environments whereas the $S_{0: 1}$ generation was evaluated in only one environment, confirming that the more environments the genotypes are evaluated for, the lower the interaction effect.

Since the beginning of the second harvest in Brazil, many soybean-breeding programs have been focused on the development of earlier cultivars. Several reports have demonstrated success when using early soybean cultivars (Gesteira et al., 2015; Pereira et al., 2017). Gesteira et al. (2015) note that in addition to optimizing the second crop, the use of early cultivars reduces pressure from pathogens. In addition to maturity earliness, the other traits evaluated in this study are also taken into account when recommending a cultivar according to the needs of the soybean producers.

\section{Conclusion}

The estimates of the variance components show the presence of variability among the progenies, enabling the selection of superior genotypes.

When selecting the earliest-maturity progenies, there are reductions in the days to flowering, plant height, Bottom pod height, lodging and grain yield.

\section{Acknowledgements}

This work it was financed in part by the Coordenação de Aperfeiçoamento de Pessoal de Nível Superior-Brasil (CAPES) - Finnancial Code 001. This work was supported by the Conselho Nacional de Desenvolvimento Científico e Tecnológico- $\mathrm{CNPq} / \mathrm{MCTIC}$, through grant of productivity to the author Adriano Teodoro Bruzi. 


\section{References}

Allard, R. W., \& Bradshaw, A. D. (1964). Implications of genotype-enviromental interactions in applied plant breeding. Crop Science, 4(5). https://doi.org/10.2135/cropsci1964.0011183X000400050021x

Barros, H. B., Sediyama, T., Fidelis, R. R., \& Capone, A. (2012). Adaptabilidade e estabilidade de genótipos de soja por meio de métodos uni e multivariado. Journal of Biotechnology and Biodiversity, 3, 49-58.

Bernard, R. L., Chamberlain, D. W., \& Lawrence, R. D. (1965). Result of the cooperative uniform soybeans tests (p. 134). Washington: USDA.

Bernardo, R. (2010). Breeding for quantitative traits in plants (2nd ed., p. 400). Woodbury: Stemma Press.

Borém, A. (2009). Hibridação Artificial de Plantas (2nd ed., Vol. 1, p. 625). Viçosa, MG: Editora UFV.

Botelho, F. B. S., Ramalho, M. A. P., \& Abreu, A. F. B. (2007). Seleção recorrente fenotípica para florescimento precoce de feijoeiro 'Carioca'. Pesquisa Agropecuária Brasileira, 42(10), 1437-1442. https://doi.org/ 10.1590/S0100-204X2007001000010

Bueno, R. D., Borges, L. L., Arruda, K. M. A., Behring, L. L., Barros, E. G., \& Moreira, M. A. (2013). Genetic parameters and genotype $\times$ environment interaction for productivity, oil and protein content in soybean. African Journal of Agricultural Research, 8(38), 4853-4859. https://doi.org/10.5897/AJAR2013.6924

Companhia Nacional de Abastecimento. (2018). Safra grãos. Brasília, Brazil. Retrieved June 10, 2018, from http://www.conab.gov.br

Gesteira, G. S., Bruzi, A. T., Zito, R. K., Fronza, V., \& Arantes, N. E. (2018). Selection of early soybean inbred lines using multiple index. Crop Science, 58(6), 2494-2502. https://doi.org/10.2135/cropsci2018.05.0295

Gesteira, G. S., Zambiazzi, E. V., Bruzi, A. T., Soares, I. O., Rezende, P. M. de, \& Silva, K. B. (2015). Seleção fenotípica de cultivares de soja precoce para a região Sul de Minas Gerais. Revista Agrogeoambiental, 7(3), 79-88. https://doi.org/10.18406/2316-1817v7n32015730

Gezan Munoz. (2014). Analysis of Experiments using ASReml: with emphasis on breeding trials.

Hoffmann, G. S. S., Ramalho, M. A. P., Abreu, A. F. B., \& Nunes, J. A. R. (2010). Estimation of genetic progress after eight cycles of recurrent selection for common bean grain yield. Crop Breeding and Applied Biotechnology, 10(4). https://doi.org/10.1590/S1984-70332010000400010

Marques, M. C., Hamawaki, O. T., Sediyama, T., Bueno, M. R., Cruz, C. D., Reis, M. S., \& Nogueira, A. P. O. (2011). Adaptabilidade e estabilidade de genótipos de soja em diferentes épocas de semeadura. Bioscience Journal, 27, 59-69.

Pereira, F., Bruzi, A. T., de Matos, J. W., Rezende, B. A., Prado, L. C., \& Nunes, J. A. R. (2017). Implications of the population effect in the selection of soybean progenies. Plant Breeding, 136(5), 679-687. https://doi.org/ $10.1111 /$ pbr. 12512

Piepho, H. P., \& Mohring, J. (2007). Computing heritability and selection response from unbalanced plant breeding trials. Genetics, 177(3), 1881-1888. https://doi.org/10.1534/genetics.107.074229

R Core Team. (2016). R: A Language and Environment for Statistical Computing. R Foundation for Statistical Computinh, Vienna, Austria. URL: http://www.R-project.org

Ramalho, M. A. P., Abreu, A. F. B., \& Santos, J. B. (2001). Melhoramento de espécies autógamas. In L. L. Nass, A. C. C. Valois, I. S. de Melo, \& M. C. Valadares-Inglis (Eds.), Recursos genéticos e melhoramento de plantas (pp. 201-230). Rondonópolis: Fundação MT.

Rocha, M. D. M., \& Vello, N. A. (1999). Interação genótipos e locais para rendimento de grãos de linhagens de soja com diferentes ciclos de maturação. Bragantia, 58(1), 69-81. https://doi.org/10.1590/S0006-87051 999000100009

Silva, K. B., Bruzi, A. T., Zuffo, A. M., Zambiazzi, E. V., Soares, I. O., Rezende, P. M., ... Coelho, M. A. O. (2015). Adaptability and phenotypic stability of soybean cultivars for grain yield and oil content. Genetics and Molecular Research, 15(2). https://doi.org/10.4238/gmr.15026756

Soares, I. O., Rezende, P. M., Bruzi, A. T., Zambiazzi, E. V., Felisberto, G., Zuffo, A. M., ... Gwinner, R. (2015). Adaptability of soybean cultivars in different crop years. Genetics and Molecular Research, 4(3), 8995-9003. https://doi.org/10.4238/2015.August.7.8 
Vasconcelos, E. S., Reis, M. S., Cruz, C. D., Sediyama, T., \& Scapim, C. A. (2010). Adaptability and stability of semilate and late maturing soybean genotypes in Minas Gerais state. Acta Scientiarum. Agronomy, 32(3), 411-415. https://doi.org/10.4025/actasciagron.v32i3.8249

Zanon, A. J., Winck, J. E. M., Streck, N. A., da Rocha, T. S. M., Cera, J. C., Richter, G. L., ... Marchesan, E. (2015). Development of soybean cultivars as a function of maturation group and growth type in high lands and in lowlands. Bragantia, 74(4).

\section{Copyrights}

Copyright for this article is retained by the author(s), with first publication rights granted to the journal.

This is an open-access article distributed under the terms and conditions of the Creative Commons Attribution license (http://creativecommons.org/licenses/by/4.0/). 